Institut für Parasitologie

der Vetsuisse-Fakultät Universität Zürich

Direktor: Prof. Peter Deplazes

Arbeit unter wissenschaftlicher Betreuung von PD Dr. Hubertus Hertzberg

Vaccination of goats against Haemonchus contortus with the gut membrane proteins H11/H-gal-GP

\author{
Inaugural-Dissertation \\ zur Erlangung der Doktorwürde der \\ Vetsuisse-Fakultät Universität Zürich \\ vorgelegt von \\ Lorena Meier \\ Tierärztin \\ von Horgen / ZH \\ genehmigt auf Antrag von \\ PD Dr. Hubertus Hertzberg, Referent
}




\section{Index}

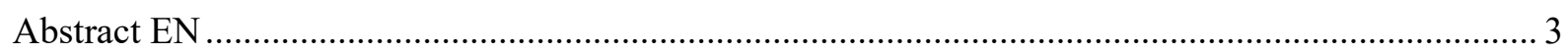

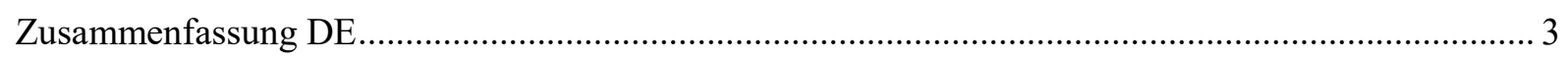

Artikel publiziert in Veterinary Parasitology (2016) Volume 229, pp. 15 -21, 2016 :

Vaccination of goats against Haemonchus contortus with the gut membrane proteins

H11/H-gal-GP. Lorena Meier, Paul R. Torgerson, Hubertus Hertzberg

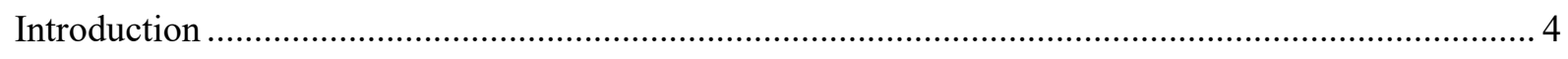

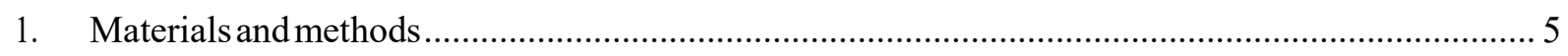

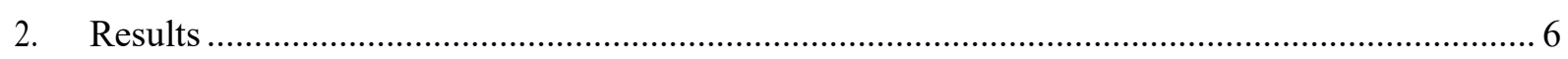

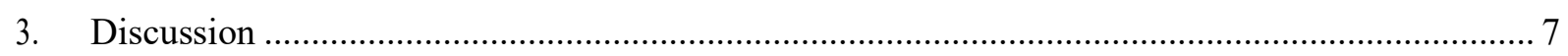

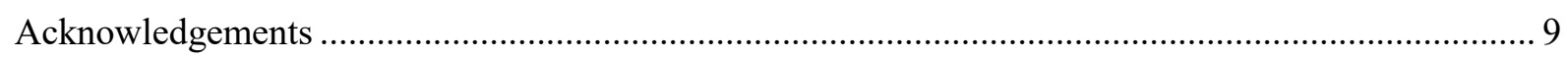

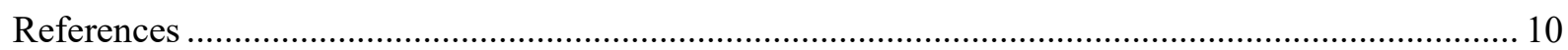

Curriculum vitae 
Vetsuisse-Fakultät Universität Zürich (2017)

\title{
Lorena Meier
}

\author{
Institut für Parasitologie, parasito@vetparas.uzh.ch
}

\begin{abstract}
Vaccination of goats against Haemonchus contortus with the gut membrane proteins H11/H-gal-GP
\end{abstract}

\begin{abstract}
To evaluate protection against Haemonchus contortus, four groups of 10 young goats each were vaccinated with the $H$. contortus gut membrane proteins $\mathrm{H} 11 / \mathrm{H}$-gal-GP either in 4week- (V4) or 6-week-intervals (V6, V6SEP). A control group (CTRL) remained unvaccinated. After the second vaccination in May all goats were turned out on pastures which had been previously contaminated with $H$. contortus eggs by seeder sheep for six weeks. Group V6SEP was grazed separately at an identical stocking rate. Clinical, parasitological and serological (vaccine antibodies) parameters were measured fortnightly. All goats were stabled in October, drenched with levamisole and two weeks later orally infected with $5000 \mathrm{~L} 3$ of $H$. contortus. Four weeks later they were slaughtered to quantify abomasal worm burdens. Significantly $(\mathrm{p}<0.01)$ lower faecal egg counts were observed in group V6SEP compared with the controls. Mean egg output of all groups fluctuated at low levels during the second part of the grazing period. Goats responded to vaccination with increasing antibody titres peaking after every booster. Mean worm burdens after experimental infections were reduced significantly $(\mathrm{p}<0.01)$ in group V4 compared with the controls. It was concluded that the vaccination protocol did not result in sufficient protection against $H$. contortus on pasture, as antibody titres were still low at the time the goats were exposed to elevated larval contamination on pasture after turnout.
\end{abstract}

Keywords: Goats, Haemonchus contortus, Vaccination, Field study

\section{Zusammenfassung}

Vier Gruppen à 10 Jungziegen wurden mit den Darmmembranproteinen H11/H-gal-GP von Haemonchus contortus entweder im 4-Wochen- (V4) oder 6-Wochen-Abstand (V6, V6SEP) geimpft, um den Schutz gegen H. contortus zu evaluieren. Eine Kontrollgruppe blieb ungeimpft (CTRL). Nach der zweiten Impfung im Mai wurden alle Ziegen auf Weiden verbracht, die vorab von Schafen während 6 Wochen mit H. contortus-Eiern kontaminiert wurden. Die Gruppe V6SEP weidete separat bei gleicher Besatzdichte. Alle 14 Tage wurden klinische, parasitologische und serologische (Vakzine-AK) Parameter gemessen. Im Oktober wurden alle Ziegen eingestallt, mit Levamisol entwurmt und zwei Wochen später mit 5000 L3 von $H$. contortus oral infiziert. Nach vier Wochen wurden sie geschlachtet und die abomasalen Wurmbürden ermittelt. Verglichen zu der Kontrollgruppe waren die Eizahlen im Kot in der Gruppe V6SEP signifikant $(\mathrm{p}<0.01)$ reduziert. Während der Weideperiode fluktuierten die durchschnittlichen Eizahlen im Kot aller Gruppen auf tiefem Niveau. Die Ziegen reagierten mit steigenden AK-Titern, die nach jedem Booster einen Peak ergaben. Nach der Kontrollinfektion waren die abomasalen Wurmbürden in Gruppe V4 verglichen mit denen der Gruppe CTRL signifikant $(\mathrm{p}<0.01)$ reduziert. Die Ergebnisse weisen darauf hin, dass die Impfprotokolle nicht in einem ausreichenden Schutz der Ziegen gegenüber $H$. contortus resultierten, da die AK-Titer zur Bewältigung des bereits bei Weideaustrieb bestehenden erhöhten Infektionsdrucks noch zu niedrig waren.

Stichwörter: Ziegen, Haemonchus contortus, Vakzinierung, Feldstudie 


\title{
Vaccination of goats against Haemonchus contortus with the gut
}

\section{membrane proteins H11/H-gal-GP}

\author{
Lorena Meier ${ }^{\mathrm{a}}$, Paul R. Torgerson ${ }^{\mathrm{b}}$, Hubertus Hertzberg ${ }^{\mathrm{a}, *}$ \\ ${ }^{a}$ Institute of Parasitology, University of Zurich, Wintherthurerstrasse 266a, 8057 Zurich, Switzerland \\ ${ }^{\mathrm{b}}$ Section of Epidemiology, Vetsuisse Faculty, University of Zurich, Winterthurerstrasse 270, 8057 Zurich, Switzerland
}

\section{ARTICLE INFO ABSTRACT}

\section{Article history:}

Received 20 March 2016

Received in revised form 23 August 2016

Accepted 31 August 2016

\section{Keywords:}

Goats

Haemonchus contortus Control

Vaccination Field

study
Forty goats, aged from 2 to 5 months were subjected to two different immunization protocols with a vaccine containing Haemonchus contortus gut membrane proteins H11/H-gal-GP to evaluate protection against $H$. contortus on pre-contaminated pastures. Goats were allocated to four groups of ten, three of them received their first vaccination before turnout. One group (V4) was then vaccinated at 4-weekintervals whereas another two groups (V6 and V6SEP) were vaccinated at 6-week-intervals. A control group (CTRL) remained unvaccinated. In May, after the second vaccination, all goats were turned out on pastures which had been previously contaminated with $H$. contortus eggs by seeder sheep for a period of six weeks. Goats of groups V4, V6 and CTRL were grazed together, whereas V6SEP was kept separately at an identical stocking rate. Clinical (PCV, FAMACHA, body weight), parasitological (faecal egg count, FEC) and serological (antibody titres) parameters were measured fortnightly. All goats were stabled in October, drenched with levamisole and two weeks later infected with 5000 L3 of $H$. contortus and slaughtered four weeks later for determination of abomasal worm burdens. Group mean FEC peaked 42-56 days after turnout. Significantly lower FEC were observed in V6SEP vs CTRL between D 28 and 70 ( $p<0.01$ ). Mean egg output of all groups decreased substantially and fluctuated at low levels until the end of the grazing period (D 154). Goats responded to vaccination with increasing antibody titres peaking after every booster. Mean worm burdens deriving from experimental infections were reduced by 89,65 and $47 \%$ in groups V4, V6 and V6SEP, respectively, compared with the controls. The difference was significant for V4 $(p<0.01)$. Antibody titres measured 14 days before slaughter did not correlate statistically with the worm burdens. It was concluded that the vaccination protocol did not result in sufficient protection on pasture, as antibody titres were still low at the time the goats were exposed to larval contamination on pasture after turnout.

(C) 2016 Elsevier B.V. All rights reserved.

\section{Introduction}

Amongst gastrointestinal nematodes (GIN), Haemonchus contor-tus is one of the most economically important parasites in goats and sheep worldwide (Zajac, 2006). Theclinical and economic losses are mainly associated with the consequences of blood-sucking activ- ity of the preadult and adult stages. Current control strategies against GIN usually rely on repeated anthelmintic treatments. As a consequence, anthelmintic resistance in ovine and caprine GIN is widespread (Saddiqi et al., 2011; Papadopoulos et al., 2012). Various alternative strategies for GIN-control have been investigated, including nematophagousfungi, bioactive forage crops and breed-

\footnotetext{
* Corresponding author.

E-mail address: hubertus.hertzberg@access.uzh.ch (H. Hertzberg).
}

ing for genetic resistance (reviewed by Waller (2006)). Specific immunization is currently the most advanced approach for nonchemical control of $H$. contortus. Most studies have been carried out in sheep based on gut membrane proteins of adult $\mathrm{H}$. contortus (Kabagambe et al., 2000; LeJambre et al., 2008), or recombinant vaccines (Cachat et al., 2010). Very few trials focused on vaccination of goats, all of them with somatic (Ruiz et al., 2004; Molina et al., 2012) or recombinant antigens (Han et al., 2012). The use of native hidden antigens based on the H11 and H-gal-GP complex has so far resulted in the highest protection in sheep (reviewed by Smith and Zarlenga (2006)). At present no published report is available on the use of native $\mathrm{H} 11$ and H-gal-GP complex in goats. Therefore a grazing experiment was performed with young goats to investigate different immunization regimes based on the H11/H-gal-GP antigen complex under the conditions of the Swiss midland region. 


\section{Materials and methods}

\subsection{Goats}

The experiment was performed with 40 castrated male Chamoix goats purchased from a local farm. The goats had been reared indoors and were fed hay and commercial pelleted rations after being weaned at the age of 8-10 weeks. They had free access to fresh water and mineralized salt. After arrival at the study site at April 2 (D-36) they were two to five months old, with an average of 106 days. Prior to the first samplings, the goats were adapted for one week to the new environment. During 4 weeks of adaptation to pasture-feeding (D-28 to 0), the goats were fed hay, weaned from pelleted food, and diet was continuously changed from hay to grass. One week after arrival, the majority of goats developed pneumonia and were treated twice within 14 days with $10 \mathrm{mg} / \mathrm{kg}$ body weight (BW) tilmicosin (Micotil ${ }^{\circledR} 300$, Provet AG Switzerland) and $0.5 \mathrm{mg} / \mathrm{kg}$ BW meloxicam (Metacam ${ }^{\circledR} 20 \mathrm{mg}$, Boehringer Ingelheim $\mathrm{GmbH}$ Switzerland). After having been base-immunized in the breeding stable, at D $\underline{28}$ all goats were boostered against Clostridium perfringens infection (Ovilis ${ }^{\circledR}$ Heptavac P, Veterinaria AG Switzerland), followed by a further immunization at the end of August.

The animal experiments were carried out in accordance with protocols approved by the Cantonal Veterinary Office (No. ZG $57 / 12)$.

\subsection{Pastures}

The trial was conducted at the experimental farm of the Federal Institute of Technology of Zurich in the canton of Zug, Switzerland $\left(47^{\circ} 10^{1} 34.99^{\prime l} \mathrm{~N}, 8^{\circ} 25^{\mathrm{l}} 35.02^{\prime \prime} \mathrm{E} ; 444\right.$ m.a.s.l.) from April to November 2012. The experimental pastures had not been grazed by farm animals during the previous year. Before the goats were transferred, the experimental pastures had been contaminated for six weeks by four adult seeder sheep, each of which had been infected with 3000 third stage larvae $\left(\mathrm{L}_{3}\right)$ of a local $H$. contortus isolate. These sheep exhibited FEC between 2440 and 5040 during the seeding period.

\subsection{Experimentaldesign}

At arrival the goats were ranked according to body weight, blocked and randomly assigned to four groups (V4, V6, CTRL, V6SEP) of 10 animals each (group average $19.9 \mathrm{~kg}$ ). At the same occasion the goats were treated anthelmintically to eliminate potential infections with GIN. Anthelmintic treatment consisted of a combination of levamisole hydrochloride and triclabendazole (Endex ${ }^{\circledR} 8.75 \%$, Novartis AG Switzerland), administered orally at a single dosage of 12 and $16 \mathrm{mg} / \mathrm{kg} \mathrm{BW}$, respectively. Levamisole was chosen as it was known to be fully effective against the selected $H$. contortus-isolate. In Switzerland, levamisole is only marketed as a combination with triclabendazole.

Absence of strongylid eggs in faeces was investigated by fae- cal egg counts and coprocultures. Goats were vaccinated with $5 \mu \mathrm{g}$ of H. contortus gut membrane proteins in $1 \mathrm{ml}$ QuilA adjuvant subcutaneously, a vaccine recently commercialized as Barbervax ${ }^{\circledR}$ (barbervax.com.au) in Australia. Prior touse, thevaccinewasstored at $4{ }^{\circ} \mathrm{C}$. Goats of groups $\mathrm{V} 4, \mathrm{~V} 6, \mathrm{~V} 6 \mathrm{SEP}$ received a basic immunization before turnout at D-28 and 0 . After turnout boosters were applied either every 4 (V4) or 6 weeks (V6 and V6SEP) for a total of 8 (V4) and 6 (V6, V6SEP) immunizations, respectively. Goats of CTRL-group remained unvaccinated. A packed cell volume (PCV) with values of less than $20 \%$ or a faecal egg count (FEC) of higher than 1000 eggs per gram (epg) were chosen as a threshold for administering a salvage treatment.
At May 8 (D 0) the animals were turned out on two adjacent pastures, designed for an average stocking rate of 125 square meters per goat. Groups V4, V6 and CTRL were grazed together on one pasture (P1), group V6SEP grazed separately (P2). The size of the paddocks was increased stepwise over the season, according to the availability of grass. The goats stayed on pasture permanently until October 9 (D 154) and were only brought into the stable for sam- plings and during one period of 4 days at the end of August, when the temperature during daytime exceeded $30{ }^{\circ} \mathrm{C}$ and goats were kept indoors during the day. Goats were only fed grass, except dur- ing the last 6 weeks at the end of the trial when they were fed hay indoors. In August, restricted to a period of two and a half weeks after they had started to lose weight, all goats were supple- mented daily with $1 \mathrm{~kg}$ hay and $400 \mathrm{~g}$ commercial pelleted rations (UFA 763, UFA AG, Switzerland). For the last phase of the trial, at D 154 all animals were treated with levamisole/triclabendazole at a dose rate as described above and housed until slaughter (on D 196/197). Herewith the different vaccination protocols could be re- evaluated after the goats had experienced the same conditions of housing/infection-pressure. So at D 168, the animals of the three vaccinated groups received a final vaccination dose, and all goats were challenged orally with 5000 third-stage-larvae of the same $H$. contortus-isolate used for seeding the experimental pastures.

\subsection{Sampling}

All goats were sampled fortnightly from D -28 until D 168, then sampling was undertaken weekly until slaughter. At the sampling days, the general condition of each goat was clinically examined by a veterinarian, which included weighing with an electronic scale (accuracy $0.1 \mathrm{~kg}$ ), and scoring for the degree of anemia (1-5) by examining the eye mucosa using the FAMACHA card (van Wyk and Bath, 2002). Individual faecal samples were collected directly from the rectum, and blood samples were collected from the jugular vein into sterile blank $9 \mathrm{ml}$ Vacuette tubes and $2 \mathrm{ml}$ Vacuette tubes containing EDTA, respectively. Despite all goats being boostered against $C$. perfringens infection, one goat died 3 days after the injection (D -25) because of peracute infection with $C$. perfringens Type D. Another goat died by asphyxiation 3 days after turnout as a consequence of a fencing accident during night. Data from those 2 goats were discarded from the calculations.

\subsection{Parasitological techniques}

FEC were performed using a modified McMaster method with a sensitivity of 50 epg (Schmidt, 1971). Eggs other than strongyles were categorized separately. For identification of infective larvae, coprocultures were made according to Eckert (1960). Pooled faecal samples of each treatment group were mixed with sawdust and incubated for 7 days at $27{ }^{\circ} \mathrm{C}$. From each culture, 100 thirdstage-larvae (L3) were morphologically differentiated according to the guidelines of MAFF (Ministry of Agriculture, 1986). Pasture contamination with infective larvae was determined according to Sievers Prekehr (1973), modified by Hertzberg et al. (1996). Every 6-8 weeks, the presence of lungworm larvae and liver fluke eggs was tested with the Baermann and sedimentation technique, respectively. After slaughter and exsanguination, the abomasa were ligated and removed immediately. The contents were washed thoroughly and filtered through a $200 \mu \mathrm{m}$ sieve. A $10 \%$ aliquot was separated and fixed with formaline at a final concentration of $4 \%$. Male and female adults and juveniles of $H$. contortus were counted under a dissecting microscope at a magnification of 50 and the total number calculated per individuum. 


\subsection{Packed cell volume and serology}

Packed cell volume (PCV) was measured within $4 \mathrm{~h}$ after blood sampling using a microcentrifuge. Serum was separated by centrifugation and stored at $20{ }^{\circ} \mathrm{C}$ until the end of the experiment. Antibody titres were determined by ELISA. Briefly, Microlon 96W microtitre plates (Greiner Labs, Scotland) were coated with $50 \mu \mathrm{l}$ of a $1 \mu \mathrm{g} / \mathrm{ml} \mathrm{H11/H-gal-GP}$ solution in sodium carbonate buffer (50 $\mathrm{mM}$ carbonate, $\mathrm{pH} 9.6$ ) overnight at $4{ }^{\circ} \mathrm{C}$. After washing the Plates 6 times with PBS, the wells were blocked with $10 \%(\mathrm{w} / \mathrm{v})$ Infasoy (Cow and Gate Ltd.) in TNTT $(10 \mathrm{mM}$ Tris- $\mathrm{HCl}, 0.5 \mathrm{M} \mathrm{NaCl}, 0.05 \%$ $\mathrm{v} / \mathrm{v}$ Tween 20,0.01\% w/v thimerosal, $\mathrm{pH} 7.4)$, incubated for $2 \mathrm{~h}$ at room temperature (RT) and washed again. Serum samples from each goat were diluted 1: 100 in TNTT, and from that a series of doubling dilutions were made from 1: 200-1: $204^{\mathrm{l}} 800$ and $50 \mu \mathrm{l}$ of each dilution was added in the wells and incubated at RT for $1 \mathrm{~h}$. After 6 washes, $50 \mu \mathrm{l}$ mouse monoclonal anti-goat/sheep IgG-horse radish peroxidase (HRPO) conjugate (Sigma Cat\#A9452) was added to each well, diluted 1: $10^{\mathrm{l}} 000 \mathrm{in}$ TNTT, and incubated $1 \mathrm{~h}$ at RT. Following 6 washings $50 \mu \mathrm{l}$ o-phenylenediaminedihydrochloride (OPD) substrate (Sigma) was added to each well. After $20 \mathrm{~min}$ of incubation at RT in the dark, the reaction was stopped by adding $25 \mu \mathrm{l}$ of $2.5 \mathrm{M}$ sulfuric acid to each well and the absorbance read at $490 \mathrm{~nm}$ with an ELISA plate reader. Individual titres of each goat are expressed as that dilution of the serum required to give the same absorbance as the negative control serum diluted 1: 200.

\subsection{Statisticalmethods}

All analysis was undertaken in R (R-Core-Team, 2015).Variation in PCVs were analysed using a linear mixed effect model. Variation in egg counts were examined using a negative binomial linear mixed effect model. AD Model builder software (Fournier et al., 2012) implemented in $\mathrm{R}$ via the glmmADMB package (Skaug et al., 2014) was used to estimate parameters of the mixed effects models. The MASS (Venables and Ripley, 2002) package was used for parameter estimation of fixed effects models. Vaccination and anthelmintic treatment were taken as fixed effects with animal as a random effect. Group means of body weight gain during the grazing season were compared with a $t$-test using IBM SPSS Statistics 21. A linear mixed model on $\log +1$ transformed data was used to compare antibody titres over the season, with goat as the random effect and date and vaccination protocol as a fixed effect. Association of total antibody titres at D 28 with the egg counts of D 42 was determined by using negative binomial regression model fixed effects model. A negative binomial model was used to compare total worm counts and the Fisher test was used to compare the percentage of female worms.

\subsection{Meteorological data}

Data on precipitation and air temperature were obtained from the national weather service. The next meteorological station was situated at an aerial distance of $5 \mathrm{~km}$ to the experimental farm. Total daily precipitation and mean daily temperature $(24 \mathrm{~h}, 2 \mathrm{~m}$ above ground) were recorded.

\section{Results}

\subsection{Faecal egg counts and larval differentiation}

The pattern of $H$. contortus FEC in all groups was characterized by a sharp increase in June (Fig. 1). At D 56 mean egg counts from groups V4, CTRL and V6SEP peaked at 4300, 4200 and 1250 epg, respectively. Mean egg excretion from group V6 reached a maximum of 2950 epg at D 42 . The peaks in the faecal egg counts were followed by a rapid decline in July and low levels from August onwards. After levamisole treatment at the end of the grazing period (D 154) egg counts turned to zero. Goats from V6SEP shed the fewest eggs during the whole trial with an overall mean of 206 epg comparing to overall means of 401 (V4), 504 (V6) and 539 (CTRL) with only the difference between V6SEP and CTRL being significant $(\mathrm{p}<0.05)$. Following larval challenge at D 168, FEC reached mean values of 5, 50, 210 and 33 at slaughter (D 196/197) in groups V4, V6, CTRL and V6SEP, respectively. The overall low levels did not allow statistical comparison during this phase. Coprocultures confirmed $H$. contortus being the only trichostrongylid nematode appearing during the whole trial. Eggs of Nematodirus battus, Trichuris ovis and Strongyloides papillosus were rarely found in faecal samples of all groups at low levels.

\subsection{Worm burden}

Mean worm burdens of all vaccinated groups were lower compared with CTRL with reductions of $88.5 \%, 65.4 \%$ and $46.5 \%$ in groups V4, V6 and V6SEP, respectively (Fig. 2). This difference was significant in group V4 $(p<0.01)$. In all groups fewer female than male worms were recovered. With a rate of female worms of 27 and $31 \%$ this difference was significant in groups V4 and V6, compared with $42 \%$ in the CTRL group $(\mathrm{p}<0.05)$.

\subsection{Packed cell volume and FAMACHA-scores}

Mean PCV values ranged between 29.5 and 31.4 at turnout (Fig. 3). Values began to decrease in all groups by D 28. Declin- ing values were observed until D 98 reaching mean levels around 20, and afterwards PCV increased constantly, up to over 30 until slaughter. Differences were not significant between the groups ( $p$ $>0.05$ ). Mean overall PCV values during the grazing season were 25.4, 24.5, 24.7 and 26.2 for V4, V6, CTRL and V6SEP, respectively.

FAMACHA scores started with values around 3.3 at turnout (Fig. 3). Values fluctuated similarly in the three vaccinated groups around values of 3.5 until D 98, and decreased to values near 3 (V4, V6) or below 3 (V6SEP) until the end of the grazing period. Overall, the highest values, indicating palest mucosa, were seen in CTRL. Mean FAMACHA scores were lowest for V6SEP (3.1), followed by V4 and V6 (both 3.3) and CTRL (3.6). FAMACHA scores 4 and 5 significantly correlated with the PCV $(p<0.005)$, but not scores 2 and $3(\mathrm{p}>0.05)$.

\subsection{Serology}

All vaccinated groups exhibited antibody titres of 7700-9700 after the third immunization (Fig. 4). Subsequently each anti- gen application stimulated an antibody response reaching highest mean titres after the 6th (V4: $\left.24^{\mathrm{l}} 504\right)$ or 5th (V6: 13'033, V6SEP: 14'099) vaccination. The linear mixed model indicated substantially higher titres for the vaccination groups compared to the controls through the grazing season (V4, p $<0.00001$, V6 p $<0.002$, V6SEP $\mathrm{p}<0.0005)$. Mean antibody titres of V6 and V6SEP followed a similar course during the trial. Titres of V4 fluctuated at higher levels compared with the other groups. Mean titres of the CTRL group increased constantly throughout the grazing period, reaching a maximum of $6^{\mathrm{I}} 376$ at D 154 and decreased immediately after anthelmintic treatment. Individual antibody titres from D 28 compared with FEC from D 42 revealed no significant correlation $(p>0.05)$. Furthermore no correlation between antibody titres from D 182 and worm burdens was found at slaughter (D 196/197). 


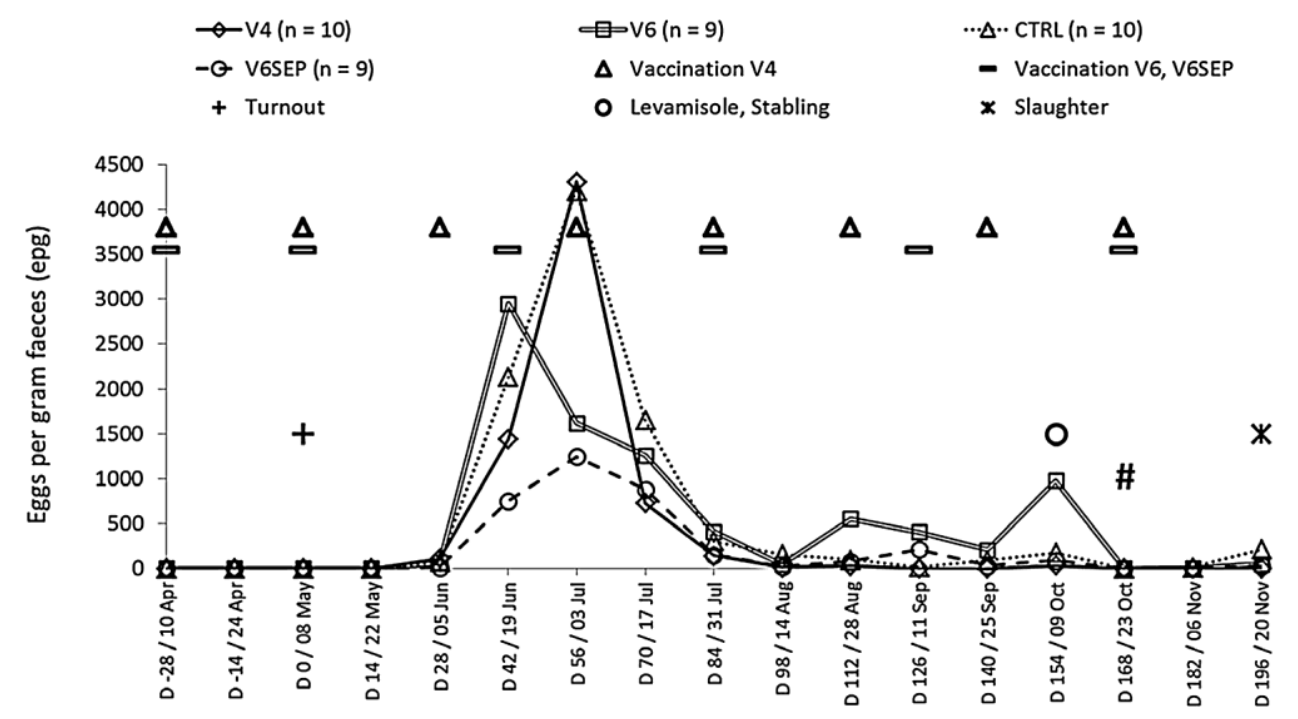

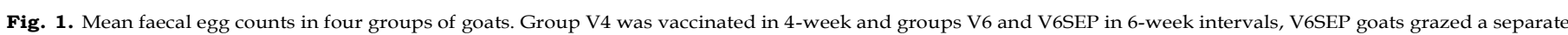

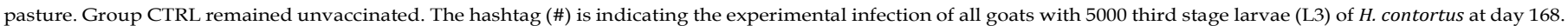

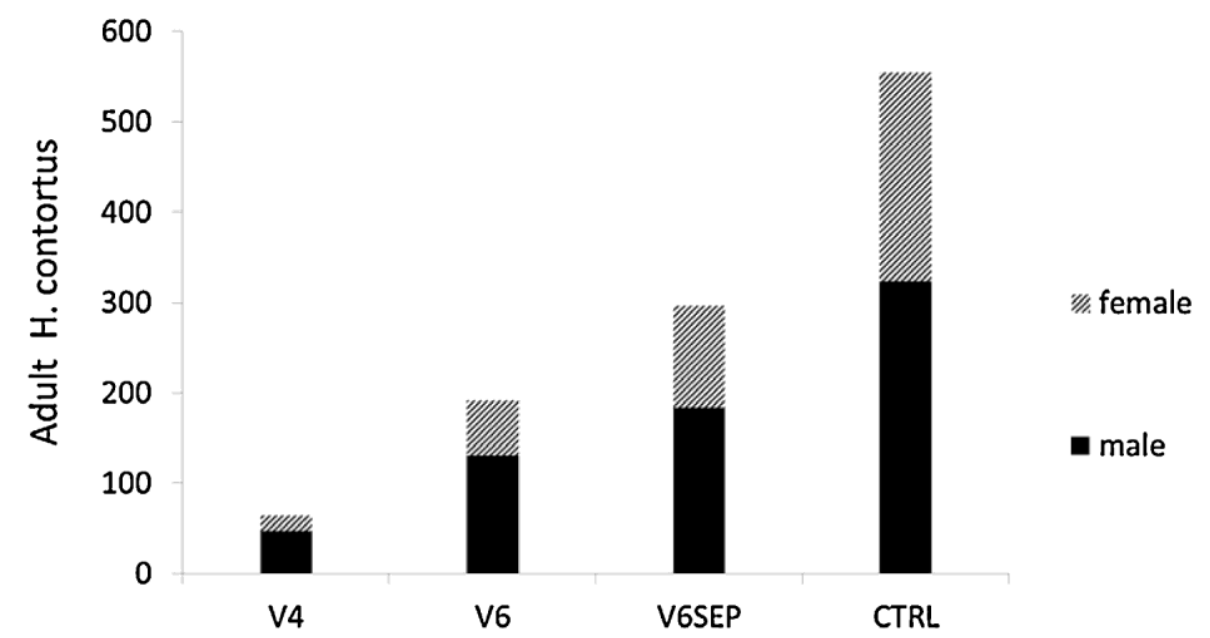

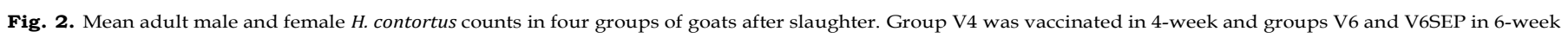
intervals, V6SEP goats grazed a separate pasture. Group CTRL remained unvaccinated.

\subsection{Body weight, clinical condition and anthelmintictreatments}

Mean group BW at turnout (D 0) ranged between $23.8-24.6 \mathrm{~kg}$. During the grazing period (D 0-154), a significant higher mean daily weight gain $(\mathrm{p}<0.05)$ was observed in groups V6 $(60 \mathrm{~g})$ and V6SEP (73 g) compared to CTRL (41 g), which represents a difference of $+47 \%$ (V6) and $+79 \%$ (V6SEP). The benefit of group V4 (+53 g) was not significant $(\mathrm{p}>0.05)$.

Clinical signs of haemonchosis were not observed during the whole experiment. In total, eighteen individual anthelmintic treatments were administered according to the preset conditions. The number of treatments was 4, 7, 1 and 6 in groups V4, V6, V6SEP and CTRL, respectively. In group V6 two goats and in group CTRL one goat had to be treated twice.

\subsection{Pasture larvalcounts}

Contamination of both pastures with $H$. contortus-larvae developed fairly similar over the whole grazing season (Fig. 5). Larval contamination increased to $2100 \mathrm{~L} 3 / \mathrm{kg}$ dry matter (DM) on P1 (grazed by V4, V6, CTRL) and 1900 L3/kg DM on P2 (V6SEP) from days42-56, and gradually decreased during AugustandSeptember to low levels in October.

\subsection{Meteorology}

Mean $24 \mathrm{~h}$ temperatures during May ranged from 10 to $21{ }^{\circ} \mathrm{C}$ (monthly average $14.9^{\circ} \mathrm{C}$ ). June, July and August were warmer with mean 24 h-temperatures between $13-25^{\circ} \mathrm{C}$ (monthly average 18.3, $18.7,20.1$, respectively). Compared to the long year average, May, June and July were about $2{ }^{\circ} \mathrm{C}$ warmer, the other months ranged close to the averages.

Rainfall occurred periodically throughout the entire grazing period. Monthly values ranged close to the long-year average except in May and July when a below average amount of rainfall was observed.

\section{Discussion}

The aim of the study was to compare different vaccination protocols based on $H$. contortus intestinal membrane glycoproteins (H11/H-gal-GP complex) in their ability to induce protection against $H$. contortus infection in young, naïve goats grazing pre- 


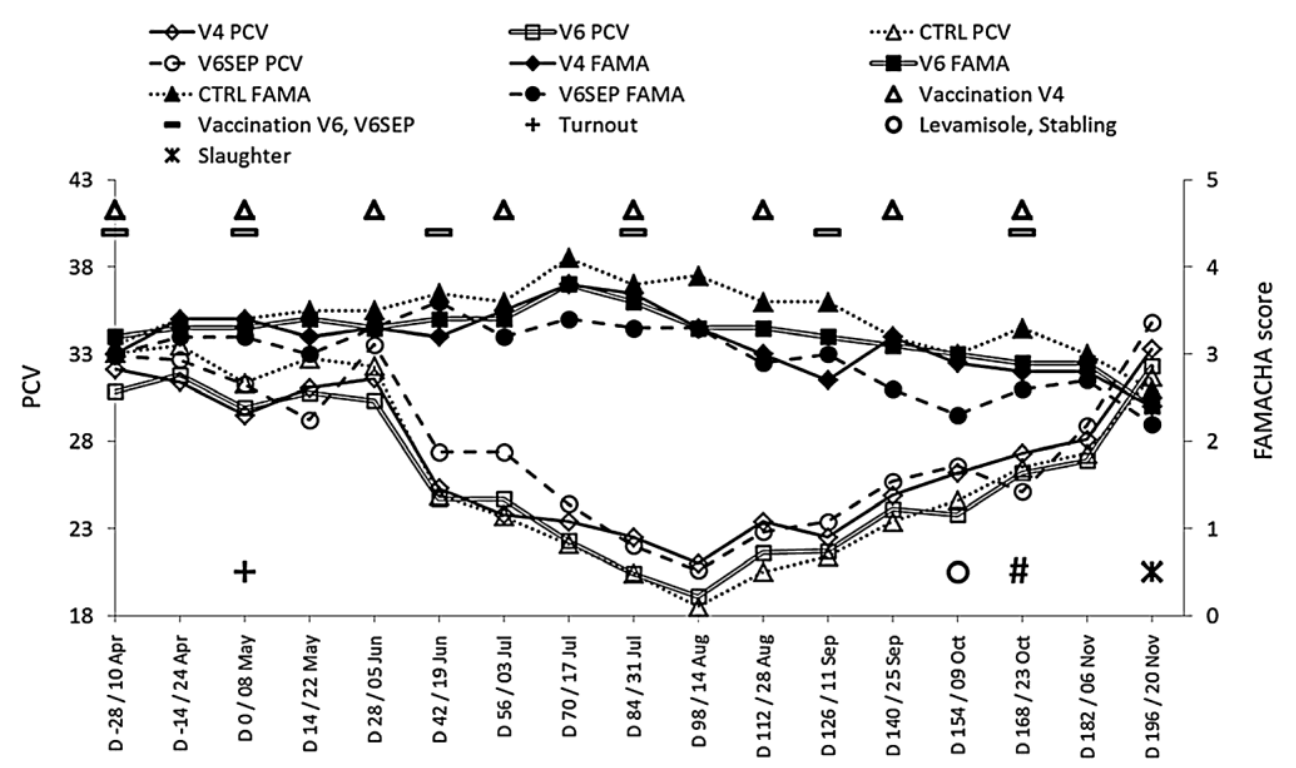

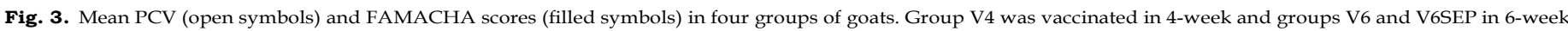

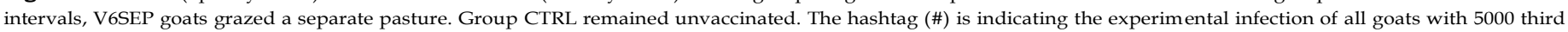
stage larvae (L3) of H. contortus at day 168.

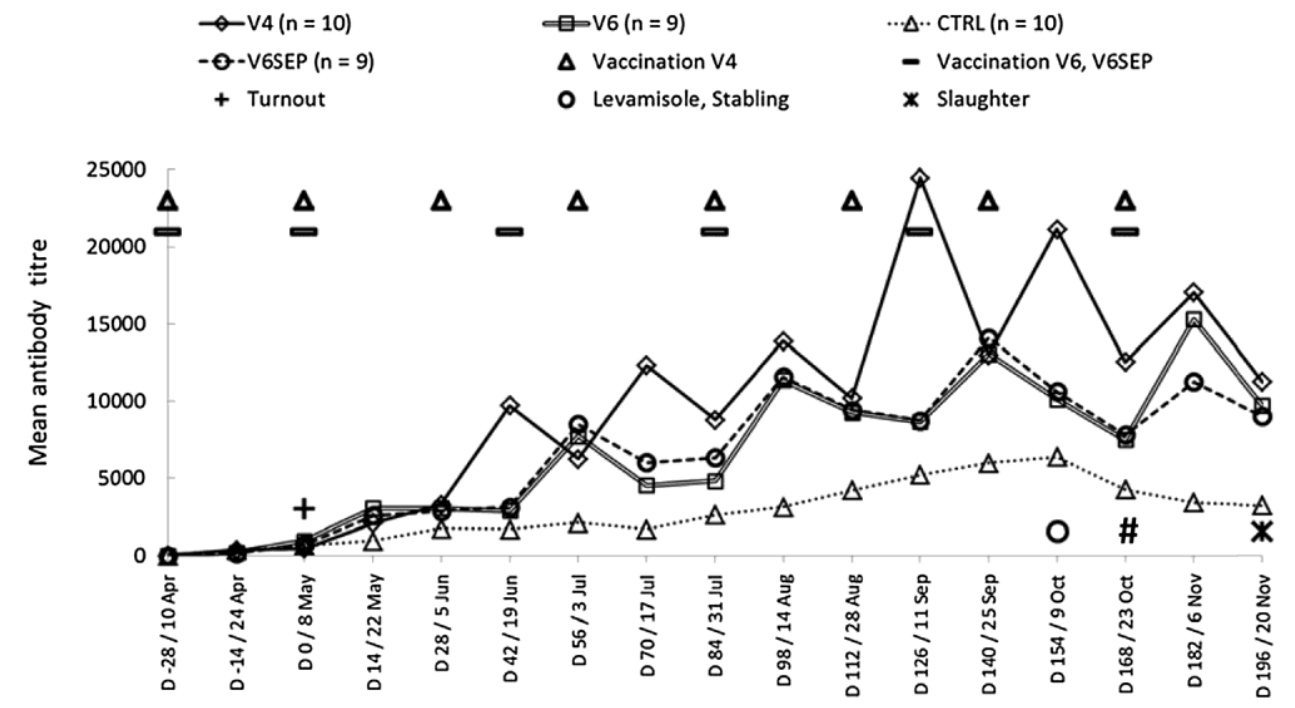

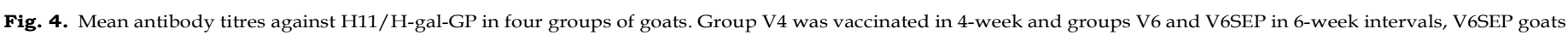

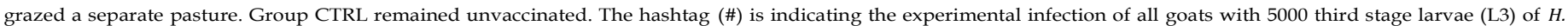
contortus at day 168 .

contaminated pastures. None of the chosen strategies was able to protect goats sufficiently as indicated by a similar development of FEC, PCV and FAMACHA. Unlike other vaccination trials performed with sheep (Andrews et al., 1997; Kabagambe et al., 2000; LeJambre et al., 2008), goat antibody titres increased slower after the first and second injection to values around 2000-3000. Therefore titres were still too low for inducing protection after turnout on contaminated pastures, which was supported by the lack of correlation of antibody titres at D 28 with the FEC two weeks later. To aquire protection against enterotoxaemia (Clostridium perfringens type D) goats need to build up higher antibody levels (Uzal et al., 1998) compared with sheep (Oxer et al., 1971). The reason for this apparently different pattern in goats and sheep is unclear, but together with the observation that antibody levels in young goats are of short duration (Uzal et al., 1998), these findings may indicate why in the present study the vaccination protocol derived from sheep was not equally successful in goats. As even with much higher antibody titres (around 60,000), protection is not complete (Bassetto et al., 2014). To our knowledge published reports about the use of native concealed antigens against $H$. contortus-infection in goats are not available to date. In comparable studies with sheep, titres of approximately 6000, (measured with the same technology) were induced four weeks after first vaccination, when animals were successfully facing larval challenge (LeJambre et al., 2008). The observation that after the third immunization of group V4 at midJune, despite titres close to $10^{\prime} 000$, there was still an increase of mean FECs two weeks later, suggests that in goats even higher titers may be necessary to induce sufficient protection; much higher than in sheep.

The vaccination protocol is clearly reflected by the zigzag- shaped development of the antibody-peaks of the vaccinated groups. This pattern is typically induced by the QuilA adjuvant used in this experiment, which is known to induce only short-termed elevations of antibody titres in sheep (Smith et al., 2000). Under 


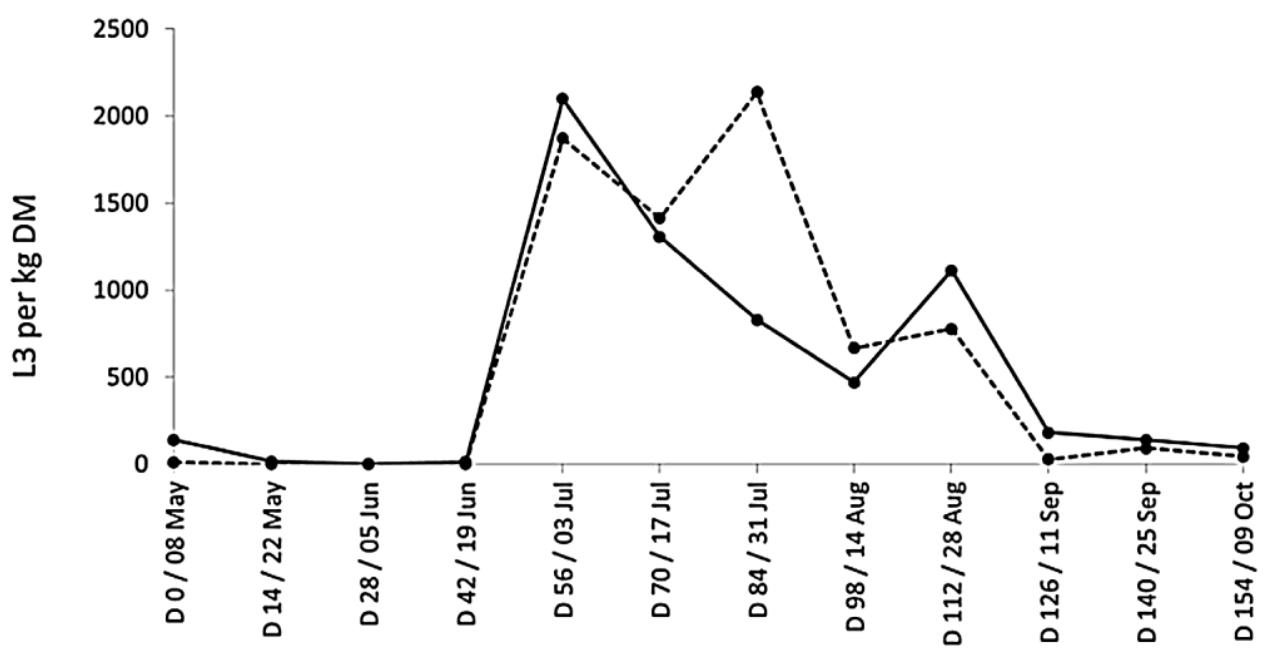

Fig. 5. H. contortus third stage larval counts on two pastures grazed either by three experimental groups (V4, V6, CTRL, Pasture 1) or one group (V6SEP, Pasture 2).

these conditions repeated injections are mandatory as the antibody response against the concealed antigens can only be marginally boostered by natural challenge (Knox et al., 2003). However, unvaccinated animals of the control group were able to generate antibody responses against the gut antigens, indicated by steadily increasing titers throughout the grazing period and immediate decline after deworming. This is supporting earlier suggestions that $\mathrm{H} 11 / \mathrm{H}-$ galGP may not be completely hidden for the immune system (Smith et al., 2001). Alternatively, unknown homologous epitopes outside the gut may simultaneously stimulate the antibody response (LeJambre et al., 2008). The initial peak in FEC in June/July was directly followed by an increase of the pasture contamination with infective larvae. While egg counts in naïve goats under continuous challenge with $H$. contortus usually remain at high levels for a longer period (Miller et al., 2011), the mean egg output of vaccinated and control goats of the present study dropped to very low levels by D 84. Most likely, the sudden increase of pasture contamination with infective larvae measured at the beginning of July has induced a self-cure reaction (Luffau et al., 1981; Adams, 1983), removing the majority of the existing infection within a very short period. Therefore, the specific role of vaccination could not be assessed after this event. Furthermore, the reason for the apparent lack of re-infection after the self-cure reaction remains unclear. Larval contamination, arising from the egg-contamination from mid-June to mid-July persisted approximately until the beginning of September. During this period sufficient pressure for reinfection should have been present. However, the very low egg output during August to September in all groups except V6 showed that all groups, including CTRL were able to successfully manage the larval challenge on pasture. The intention of running the V6SEP-group on a separate pasture was to determine the epidemiological benefit of vaccination under conditions where unvaccinated animals are excluded. Unfortunately, due to the low egg excretion in all groups during the second part of the grazing season, the consequences of a reduced larval contamination on the V6SEP-pasture could not be assessed. However, despite a substantially lower number of necessary treatments in the V6SEPgroup, these goats exhibited a significantly higher weight gain, suggesting an epidemiological benefit for vaccinating the entire group.

Worm burdens deriving from experimental infection at the end of the trial were significantly lower in group V4 compared with CTRL and the percent of female worms was significantly reduced in groups V4 and V6 compared to CTRL, most likely indicating the higher blood intake of the female worms (Smith and Smith, 1993). Although the mean antibody titres of V4 measured 14 days before necropsy reflected the higher intensity of vaccination in this group, no correlation was found between the individual titres and the worm burden at necropsy. This might have been caused i) by the limited group size or ii) by the relatively low mean worm burden in all groups, which most likely reflects an additional immune protection induced by $H$. contortus-infection.

Under farming conditions in Switzerland and bordering countries adult goats are responsible for initial contamination of the pastures with $H$. contortus-eggs in spring, mimicked by the seeder sheep in the present study. For indoor-born kids a sufficient time period should be made available for a set of three vaccinations in 3-week intervals, which, according to the present results, will most likely be necessary to protect the offspring against larval challenge after turnout. A more difficult situation is arising for kids born close to or even after turnout. Here, assuming an age of 4 weeks for the first vaccination, kids would be aged approximately 11 weeks before immune protection has developed sufficiently, which in most cases will be too late to avoid a scenario experienced in the presentstudy.

The results document the challenge to synchronize vaccina- tion against $H$. contortus with the farm management. For achieving similar results as in sheep (LeJambre et al., 2008), additional studies are needed to develop a vaccination protocol able to sufficiently protect young goats in a $H$. contortus-dominated environment.

\section{Acknowledgements}

We are grateful to Dr. David Smith and Dr. George Newlands of the Moredun Research Institute for providing Barbervax ${ }^{\circledR}$ and Margaret Oliver for performing the serology. The excellent support from the staff at the Chamau experimental farm is greatly acknowledged. Furthermore, we thank Marion Fasel from the Extension and Health Service for Small Ruminants, for helpful advice and medical support. Financial support for this project from the state Secretariat for Education, Research and Innovation SERI is acknowledged (SERI/COST C10.0084). The Project has been embedded in COST Action FA0805 (Goat-parasite interactions: from knowledge to control (CAPARA)). 


\section{References}

Adams, D.B., 1983. Observations on the self-cure reaction and other forms of immunological responsiveness against Haemonchus contortus in sheep. Int. J. Parasitol. 13, 571-578.

Andrews, S.J., Rolph, T.P., Munn, E.A., Taylort, M.A., 1997. Duration of protective immunity against ovine haemonchosis following vaccination with the nematode gut membrane antigen H11. Res. Vet. Sci. 62, 223-227.

Bassetto, C.C., Picharillo, M.E., Newlands, G.F., Smith, W.D., Fernandes, S., Siqueira, E.R., Amarante, A.F., 2014. Attempts to vaccinate ewes and their lambs against natural infection with Haemonchus contortus in a tropical environment. Int. J. Parasitol. 44, 1049-1054.

Cachat, E., Newlands, G.F., Ekoja, S.E., McAllister, H., Smith, W.D., 2010. Attempts to immunize sheep against Haemonchus contortus using a cocktail of recombinant proteases derived from the protective antigen, H-gal-GP. Parasite Immunol. 32, 414-419.

Eckert, J., 1960. Die Diagnose des Magen-Darm-Strongylidenbefalls des Schafes durch Differenzierung der freilebenden dritten Larven. Zentralbl. Vet. Med. 7, 612-630.

Fournier, D.A., Skaug, H.J., Ancheta, J., Ianelli, J., Magnusson, A., Maunder, M.N., Nielsen, A., Sibert, J., 2012. AD Model Builder: using automatic differentiation for statistical inference of highly parameterized complex nonlinear models. Optim. Methods Software 27, 233-249.

Han, K., Xu, L., Yan, R., Song, X., Li, X., 2012. Vaccination of goats with glyceraldehyde-3-phosphate dehydrogenase DNA vaccine induced partial protection against Haemonchus contortus. Vet. Immunol. Immunopathol. 149, 177-185.

Hertzberg, H., Durgiai, B., Schnieder, T., Kohler, L., Eckert, J., 1996. Prophylaxis of bovine trichostrongylidosis and dictyocaulosis in the alpine region: comparison of an early and late administration of the oxfendazole pulse release bolus to first year grazing calves. Vet. Parasitol. 66, 181192.

Kabagambe, E.K., Barras, S.R., Li, Y., Pena, M.T., Smith, W.D., Miller, J.E., 2000.

Attempts to control haemonchosis in grazing ewes by vaccination with gut membrane proteins of the parasite. Vet. Parasitol. 92, 15-23. Knox, D.P., Redmond, D.L., Newlands, G.F., Skuce, P.J., Pettit, D., Smith, W.D., 2003. The nature and prospects for gut membrane proteins as vaccine candidates for Haemonchus contortus and other ruminant trichostrongyloids. Int. J. Parasitol. 33, 1129-1137.

LeJambre, L.F., Windon, R.G., Smith, W.D., 2008. Vaccination against Haemonchus contortus: performance of native parasite gut membrane glycoproteins in Merino lambs grazing contaminated pasture. Vet. Parasitol. 153, 302-312.

Luffau, G., Pery, P., Petit, A., 1981. Self-curve and immunity following infection and reinfection in ovine haemonchosis. Vet. Parasitol. 9, 57-67. Miller, J.E., Burke, J.M., Terrill, T.H., Kearney, M.T., 2011. A comparison of two integrated approaches of controlling nematode parasites in small ruminants. Vet. Parasitol. 178, 300-310.

Ministry of Agriculture, F.a.F., 1986, Manual of Veterinary Parasitological Techniques. Reference Book 418HMSO.

Molina, J.M., Martin, S., Hernandez, Y.I., Gonzalez, J.F., Ferrer, O., Ruiz, A., 2012.

Immunoprotective effect of cysteine proteinase fractions from two Haemonchus contortus strains adapted to sheep and goats. Vet. Parasitol. 188, 5359 .

Oxer, D.T., Minty, D.W., Liefman, C.E., 1971. Vaccination trials in sheep with clostridial vaccines with special reference to passively acquired Cl. welchii type D antitoxin in lambs. Aust. Vet. J. 47, 134-140.

Papadopoulos, E., Gallidis, E., Ptochos, S., 2012. Anthelmintic resistance in sheep in Europe: a selected review. Vet. Parasitol. $189,85-88$. R-Core-Team, 2015. R: A Language and Environment for Statistical Computing. R Foundation for Statistical Computing, Vienna, Austria http://www.R-project. org/.

Ruiz, A., Molina, J.M., Gonzalez, J.F., Conde, M.M., Martin, S., Hernandez, Y.I., 2004. Immunoprotection in goats against Haemonchus contortus after immunization with cysteine protease enriched protein fractions. Vet. Res. 35, 565-572.

Saddiqi, H.A., Jabbar, A., Sarwar, M., Iqbal, Z., Muhammad, G., Nisa, M., Shahzad, A., 2011. Small ruminant resistance against gastrointestinal nematodes: a case of Haemonchus contortus. Parasitol. Research 109, 1483-1500.

Schmidt, U., 1971. Parasitologische Kotuntersuchung durch ein neues Verdünnungsverfahren. Tierärztliche Umschau 26, 229-230.

Sievers Prekehr, G.H.C., 1973. Methode zur Gewinnung von 3. Strongylidenlarven aus dem Weidegras. Vet.med. Thesis. School of Veterinary Medicine, Hannover.

Skaug, H., Fournier, D., Bolker, B., Magnusson, A., Nielsen, A., 2014. Generalized Linear Mixed Models using AD Model Builder R package version 0 8.0. (available from: http://glmmadmb.r-forge.r-project.org/).

Smith, W.D., Smith, S.K., 1993. Evaluation of aspects of the protection afforded to sheep immunised with a gut membrane protein of Haemonchus contortus. Res. Vet. Sci. 55, 1-9.

Smith, W.D., Zarlenga, D.S., 2006. Developments and hurdles in generating vaccines for controlling helminth parasites of grazing ruminants. Vet. Parasitol. 139, 347-359.

Smith, W.D., Smith, S.K., Pettit, D., Newlands, G.F., Skuce, P.J., 2000. Relative protective properties of three membrane glycoprotein fractions from Haemonchus contortus. Parasite Immunol. 22, 63-71.

Smith, W.D., van Wyk, J.A., van Strijp, M.F., 2001. Preliminary observations on the potential of gut membrane proteins of Haemonchus contortus as candidate vaccine antigens in sheep on naturally infected pasture. Vet. Parasitol. 98, 285-297.

Uzal, F.A., Bodero, D.A., Kelly, W.R., Nielsen, K., 1998. Variability of serum antibody responses of goat kids to a commercial Clostridium perfringens epsilon toxoid vaccine. Vet. Rec. 143, 472-474.

Venables, W.N., Ripley, B.D., 2002. Modern Applied Statistics with S, Fourth ed.

Springer, New York

Waller, P.J., 2006. From discovery to development: current industry perspectives for the development of novel methods of helminth control in livestock. Vet. Parasitol. 139, 1-14.

van Wyk, J.A., Bath, G.F., 2002. The FAMACHA system for managing haemonchosis in sheep and goats by clinically identifying individual animals for treatment. Vet. Res. 33, 509-529.

Zajac, A.M., 2006. Gastrointestinal nematodes of small ruminants: life cycle, anthelmintics, and diagnosis. Vet. Clin. North Am. Food Anim. Pract. 22, 529-541. 


\section{Curriculum Vitae}

Vorname Name

Geburtsdatum

Geburtsort

Nationalität

Heimatort

08/1989-08/1995

08/1995 - 08/1998

08/1998-08/2002

30.08.2002

$10 / 2003-10 / 2008$

20.10.2008

$11 / 2011-07 / 2013$

02/2009-07/2011

05/2013 - heute
Lorena Meier

25.1.1983

Horgen, ZH

Schweizerin

Horgen, ZH

Primarschule, Horgen, Schweiz

Sekundarschule, Horgen, Schweiz

Kantonsschule, Küsnacht, Schweiz

Matura, Kantonsschule, Küsnacht, Schweiz

Studium der Veterinärmedizin, Universität Zürich, Schweiz

Abschlussprüfung vet. med., Universität Zürich, Schweiz

Anfertigung der Dissertation

unter Leitung von PD Dr. Hubertus Hertzberg

am Institut für Parasitologie

der Vetsuisse-Fakultät Universität Zürich

Direktor Prof. Peter Deplazes

Vet. med. Assistentin für Nutztiere, Tierärztliches

Praxiszentrum Winzap \& Bächler, Brunnen, Schweiz

Vet. med. Assistentin für Kleintiere, Gross- und

Kleintierpraxis Grünau, Reiden, Schweiz 